A Journal of Culture, English Language, Teaching \& Literature

ISSN 1412-3320 (Print), ISSN 2502-4914(Online)

Vol. 16 No. 2; December 2016

Copyright @ Soegijapranata Catholic University, Indonesia

USING DICTATION TO PROMOTE THE USE OF GRAMMAR KNOWLEDGE IN RECONSTRUCTING LISTENING TEXT

Hesthi Herusatoto

English Department, English Literature Study Program, School of Foreign

Languages (STBA) LIA, Yogyakarta, Indonesia

$\mathrm{Ph}:$

Email:

$+628122773378$

hesty_h3@yahoo.com

Received: 04-12-2016

Accepted: 23-02-2017

Published: 28-02-2017 


\title{
USING DICTATION TO PROMOTE THE USE OF GRAMMAR KNOWLEDGE IN RECONSTRUCTING LISTENING TEXTS
}

\author{
Hesthi Herusatoto \\ hesty_h3@yahoo.com \\ English Department, English Literature Study Program, \\ School of Foreign Languages LIA, Yogyakarta, Indonesia
}

\begin{abstract}
This paper reports the findings of the implementation of full dictation and partial dictation in improving the awareness of using grammar knowledge in reconstructing listening texts among the EFL students at STBA (School of Foreign Languages) LIA Yogyakarta. Three groups participated in the study, i.e. two experimental groups (Group A and B) and a control group (Group C). A pre-test on listening to lectures was administered to the three groups. Over 9 sessions, Group C did the listening exercises in their textbook using dicto-comp technique, while in addition to the listening exercises which applied dicto-comp, the students in Group A was given full dictation exercises and Group $\mathrm{B}$ received partial dictation exercises. A post-test was given to the three groups after the ninth session. In addition to the post-test, a 5-point Likert-scale questionnaire assessing the students' responses to the dictation exercises was given to the experimental groups. Results of paired-samples tests indicated that there was a significant difference between each group's pre- and post-test. The mean gain score of Group B was higher than Group A showing that Group B had better improvement in the post-test. Furthermore, Group B had better grammar points in their posttest compared to Group A. Group C also increased their scores but they still got their teacher's assistance to point out their grammatical mistakes in their notes. This suggests that the dictations given to the experimental groups improved the students' awareness in applying their grammar knowledge to reproduce a listening text they heard
\end{abstract}

Key words: full dictation, partial dictation, dicto-comp, listening skills, grammar knowledge 


\begin{abstract}
Abstrak: Artikel ini melaporkan penggunaan dikte penuh dan dikte sebagian untuk meningkatkan kesadaran mahasiswa yang belajar bahasa Inggris sebagai bahasa asing di STBA (Sekolah Tinggi Bahasa Asing) LIA Yogyakarta dalam menggunakan ilmu tata bahasa pada saat menulis kembali teks menyimak. Dalam penelitian ini ada tiga kelompok responden, yaitu dua kelompok eksperimen (Grup A dan B) dan satu kelompok kontrol (Group C). Pre-test menyimak monolog diberikan pada ketiga kelompok tersebut. Selama 9 pertemuan, Grup C mendapatkan latihan menyimak yang tersedia di buku teks mereka dan mengerjakannya dengan teknik dicto-comp. Mahasiswa di Grup A mendapatkan tambahan latihan dengan dikte penuh sedangkan Grup B latihan dengan dikte sebagian di samping latihan dengan dicto-comp. Posttest diberikan kepada tiga grup itu setelah pertemuan ke-9. Kelompok eksperimen juga mendapat kuesioner berskala Likert 5 poin untuk mengukur pendapat mereka terhadap latihan dikte yang mereka dapat. Hasil dari pair-samples test menunjukkan bahwa ada perbedaan yang siknifikan antara nilai pre- dan posttest masing-masing grup. Perbedaan nilai pre-dan post-test Grup B lebih tinggi dibandingkan Grup A. Hal ini menunjukkan bahwa kemampuan Grup B meningkat lebih baik pada post-test. Selain itu, nilai poin tata bahasa Grup B pada post-test lebih bagus dibandingkan Grup A. Nilai Grup C juga meningkat namun mereka masih menerima bantuan dari dosen mereka yang menunjukkan kesalahan-kesalahan tata bahasa pada tulisan mereka. Hal ini menunjukkan bahwa dikte yang diberikan kepada kelompok eksperimen meningkatkan kesadaran mahasiswa dalam menggunakan tata bahasa untuk menulis kembali teks menyimak yang mereka dengar.
\end{abstract}

Kata kunci: dikte penuh, dikte sebagian, dicto-comp, keahlian menyimak, ilmu tata bahasa

\title{
INTRODUCTION
}

Listening which, according to Underwood (1989, p.1), is "the activity of paying attention to and trying to get meaning from something that we hear" is regarded as a receptive or passive skill in language learning. This makes this language skill often neglected in second language learning since teachers and 
students mostly focus on the productive skills, speaking and writing. Marzban and Abdollahi (2013) believe that "listening is not a passive process, ... but rather a complex process, in which the listener constructs meaning using both his/her linguistic and non-linguistic knowledge" (p.238). Thus, teachers need to give attention to the teaching technique to help students develop their listening comprehension skills and to use their linguistic and non-linguistic knowledge in comprehending and reconstructing the listening text they heard.

In reconstructing a listening text, a common problem that EFL students might face is writing words they heard with correct spelling and grammar. In Listening to Monologue classes at STBA (School of Foreign Languages) LIA Yogyakarta such common problem is always found as students tend not to proofread what they have written when reconstructing a listening text and answering listening comprehension questions. They depend on their teacher for reminding them about errors in spelling and grammar. This makes the teacher concerned as students might think that accurate spelling and grammar is not necessary when reconstructing a listening text. In fact, when reconstructing a listening text or answering listening comprehension questions, knowledge about grammar is necessary to proofread students' work.

This study applied dictations to help students improve their noticing skill when reconstructing a listening text. Dictation which can be used in listening and writing practices is "a technique where the learners receive some spoken input, hold this in their memory for a short time, and then write what they heard" (Nation, 1991, p.12). This technique is believed to help learners "focus on phrase- and clause-level construction" (p.12). Various types of dictation such as partial dictation, full dictation, and elicited imitation can be used in language learning.

The traditional technique used in the Listening to Monologue classes is dicto-comp. Dicto-comp which is derived from "dictation and composition" is regarded by Nation (1991, p.14) as "an experience technique". It is a type of dictation exercise in which students take notes the key words and ideas in a listening text while listening. Using the key words and ideas students then rewrite the text. This dictation exercise can develop students' listening and note-taking skills. This study investigated the use of other types of dictation in addition to the dicto-comp in the Listening to Monologue class. Two types of dictation, i.e. full and partial dictations are implemented in this study to see their effects on students' awareness in applying their grammar knowledge in rewriting an English lecture. Thus, the purposes of this study was to find out whether those two types of dictation independently prompted students to use 
their grammar knowledge in reconstructing a lecture in English and to examine the students' responses on the dictations given in terms of their effectiveness to improve word spelling, to use proper words in context, and to use grammar knowledge to proofread students' work.

The study was an experimental one with a three-group design: two experimental groups and one control group. It used a pre-test and a post-test to get the data. The participants were students at the Department of English and Literature at STBA LIA Yogyakarta who took Listening to Monologue class.

The questions addressed in this study were as follows:

1. Is there any significant difference between the pre- and post-test scores of each group?

2. Does the use of full and partial dictations improve the students' awareness of applying their grammar knowledge in reconstructing a listening text?

3. What are the students' responses on the dictation exercises they receive in terms of their effectiveness to develop word spelling, to use proper words in context, and to use grammar knowledge to proofread students' written texts?

Research Question 1 tests the following hypothesis:

1. Ho: There is no significant difference between the pre- and post-test scores of the group given full dictation, of the group given partial dictation, and of the control group.

2. Ha: There is a significant difference between the pre- and post-test scores of the group given full dictation, of the group given partial dictation, and of the control group.

The hypothesis is tested by using the paired-samples test to compare the means of the pre- and post-tests of each group.

Some studies have looked at the effects of dictation on students' listening comprehension and found that the students improved their listening comprehension skills after practicing by using dictation. A study conducted by Kondo (2005) examined the effectiveness of news dictation practice in listening on 55 EFL Japanese students learning English at the department of 
English and literature at Waseda University. The study revealed that the students showed improvement in the scores of their homework which was given after the treatment using dictation.

A study done by Marzban and Abdollahi (2013) that used partial dictation for listening practice in Iranian Intermediate EFL class reported similar findings in that the mean scores of the experimental group surpassed the control group. They found that partial dictation helped "learners focus on the language form of phrase and clause level constructions as well as the one at lexis level" (p.243).

That dictation practice has positive effects on students' listening ability is also shown in Kuo's findings (2010) in a study with 31 Taiwanese Engineering students enrolled in a Freshman English intermediate-level course. She supplied the students with partial dictation to an English teaching radio program. She found that the partial dictation effectively improve the listening comprehension of the students. The questionnaires she distributed to the students showed that the students agreed with the idea that the dictation helped their listening and improve their comprehension.

Tang (2012) in a study conducted to 85 Chinese studying at Guilin University of Technology examining the use of dictation to facilitate students memorizing English vocabulary also revealed that the dictation given to the students was an effective strategy which could develop the students' vocabulary and learning outcomes.

In addition, Habibi, Nemati, and Habibi (2012) conducted a study with 80 EFL students at Islamic Azad University, Sanandaj Branch to examine the role of listening comprehension in dictation and if the listening instructions can improve dictation. Their findings suggest that dictation indeed developed listening skills which was shown by the experimental group which performed better in dictation.

The findings mentioned above show that dictation appears to be effective in helping students develop their listening comprehension skills. This study examined full and partial dictations which were used as additional exercises to dicto-comp practice in order to see the effects of those two types dictation on the awareness of the Indonesian students in applying their English grammar knowledge to reconstruct a listening text in English. 


\section{LITERATURE REVIEW}

\section{A. Definition of Dictation}

Dictation is "a technique where the learners receive some spoken input, hold this in their memory for a short time, and then write what they heard" (Nation, 1991, p.12). Nation claims that dictation involves "listening input" and "written output" as learners need to use their listening skill to process what they hear and to use their writing skill to produce what they heard in written form. Its focus is on accuracy (1991, p.12).

In its traditional form, dictation is defined as a technique for teaching in which "a text is either read by the teacher or played on a cassette tape once straight through while the students just listen and try to understand. The text is broken down into a number of short sections with a pause between each section. During that pause the students have to write down what they have heard" (Norris, 1993, p.72).

Dictation is a technique used not only for teaching a foreign language. It is also used to test foreign languages. Richards and Schmidt in Longman Dictionary of Language Teaching and Applied Linguistics defines dictation as "a technique used in both language teaching and language testing in which a passage is read aloud to students or test takers, with pauses during which they must try to write down what they have heard as accurately as possible" (2002, p.157).

\section{B. Language Skills and Areas Developed through Dictation}

Conducting dictation as part of classroom activities, according to a resource package entitled Using Dictation to Develop Pupil's Listening and Writing Skills, can develop some language skills and promote language learning. It develops students' phonics skills, listening skills, note-taking skills, writing skills as well as motivates students to become autonomous learners. In addition, it promotes assessment for learning (2011, p.6).

The resource package Using Dictation to Develop Pupil's Listening and Writing Skills (2011) also denotes that phonics skills are enhanced through dictation activities which involve spelling and pronouncing words. Students listen to words or phrases to understand letter-sound relationships. It is also pointed out that listening skills developed through dictation can include skills in "discriminating sounds, stress and intonation, identifying key words, identifying main ideas, and understanding the connection between ideas" 
(2011, p.8). Furthermore, note-taking skills are applied when students note down the key words of a listening text and writing skills are enhanced when students rewrite the text using their knowledge of language.

To motivate students become autonomous learners, Using Dictation to Develop Pupil's Listening and Writing Skills (2011) mentions that dictation can be used as an extended activity. After listening to a text under a specific topic or theme, teacher can ask students to find words that relate to the topic/theme (p.10). Regarding assessment for learning, teacher can encourage students to proofread their notes after dictation activities. Teacher might provide constructive feedback to students' notes by drawing students' attention to make use of context to check the correct vocabulary. Also, teacher may ask students to apply their grammar knowledge to check verb forms and to apply their phonic skills to check spelling (p.11).

Nation (1991) views dictation as having "listening input and written input" (p.12). Thus, doing dictation activity fosters listening skill as "learners receive some spoken input" and develops writing skill as "learners write what they heard." He states that the learners' writing "is affected by their skill at listening."

Morris (1983) considers dictation "a means of encouraging correct spelling in any piece of written work" as well as "a means of reinforcing structure and vocabulary" (p.125). She believes that dictation is "a most useful tool in listening training" so that teachers might use it as one of their teaching techniques in class.

Likewise, Frodesen (2001) agrees that dictation enhances students' grammar, vocabulary, and writing. It is indeed an "effective way to familiarize students with the ways in which grammar and vocabulary interact in common collocations as well as to address errors in writing that may result in part from mismatches between learners' aural perception of English forms and standard English grammar and spelling" (p.243).

Norris (1993) who investigated Japanese university and college false beginners of English found that the implementation of creative dictation exercises (dialogue dictation race, numbers dictation, pronunciation relay, building with rods, and picture dictation) in the students' English classes motivated the students "by providing practice in several areas (e.g. accuracy, fluency, self-correction, negotiation of meaning, etc) while combining the speaking, listening, writing, and reading skills" (pp.78-79). Norris further 
quoted Davis and Rinvolucri's statement saying that "dictation of any kind provides a nice blend of listening, writing, and checking through reading." (p.79).

Alkire (2002) pointed out that dictation helps the development of "all four language skills in an integrative way." It also "develops short-term memory", provides students with "practice in correct forms of speech", in note-taking, and in "comprehending and transcribing clear English prose." In addition, it raises students and teacher's awareness of "the students' comprehension errors -phonological, grammatical, or both", as well as spelling errors. He agrees with Finocchiaro (1969) who mentions that "[dictation] ensures attentive listening; it trains pupils to distinguish sounds; it helps fix concepts of punctuation; it enables pupils to learn to transfer oral sounds to written symbols; it helps to develop aural comprehension; and it assists in self-evaluation." (Alkire, 2002).

Similarly, Kondo (2005) and Kazazoglu (2013) on their studies which implemented dictation agree that dictation used in class not only can enhance students' listening comprehension skill but also can encourage students to apply their knowledge of grammar. Kiany and Shiramiry's study (2002) also proved that frequent dictation given to sixty Iranian elementary EFL students improved the students' listening comprehension.

\section{Dictation Types}

There are four types of dictation, according to Sawyer and Silver (1961 in Alkire 2002). The first is phonemic item dictation which focuses on "the individual sounds of a language." The second is the extended form of the first type dictation, i.e. phonemic text dictation. Here, a text is phonetically transcribed by students. The third is orthographic item dictation, in which students transcribe "individual words in isolation" presented by teacher. The last is orthographic text dictation which requires students to "transcribe a unified passage".

In Habibi et al. (2012, p.3208-3209), dictation is classified into five groups, namely standard dictation, partial dictation, elicited imitation, Dictocomp, and dictation with competing noise. Standard dictation is when teacher dictates a text and students write what they hear as accurately as possible. This type of dictation is called simple dictation by Takeuchi (1997), and in this research is called full dictation. Partial dictation or which is called clued dictation by Takeuchi (1997) is when teacher reads a text and students complete the gaps in the incomplete form of the text they receive while 
listening.. Elicited imitation is a type of dictation in which students listen and imitate the text dictated by teacher. In Dicto-comp, students listen to a text dictated to them, try to get the ideas of the text, and then rewrite the text. Dictation with competing noise is similar, except students listen to a text with an extra noise in the background.

\section{Dictation Activities}

There are various dictation activities that language teachers can use in their class. Below are dictation activities that help develop students' phonics skills, grammar and vocabulary knowledge, and note-taking and writing skills as mention in Using Dictation to Develop Pupil's Listening and Writing Skills resource package.

To develop phonics skills, the dictation activity is called phonics dictation. Students learn "letter-sound relationship" and use their knowledge of listening, spelling, and writing (pp.38-40). The exercises given can be in the form of fill-in gaps in which students complete the gaps in a sentence with the target letter sounds. For example, the target letter sounds of ' $\mathrm{f}$ ' and ' $\mathrm{v}$ ' in the sentence 'The kids have some _un in the _an' ; and the letter sounds of 'ai' and ' $a$ ' in the sentence 'She take c_re of her h__r tenderly.'

To enhance the knowledge of grammar and vocabulary, picture dictation, theme-based dictation, and 'Bad Cold' dictation activities can be used. In picture dictation, students are asked to listen to the audio or teacher and draw or complete a picture based on what they hear (p.49). For instance, teacher gives a picture of an empty bedroom and students are asked to draw the locations of some items in the bedroom based on the text they hear. Such exercise allows students to learn vocabulary of things in bedroom and language items of prepositions of place. This kind of picture dictation is also called Art and Dictation (Alsadat and Hassankiadeh, 2013, p.132). In themebased dictation, students are encouraged to learn autonomously and develop their vocabulary with different themes (pp.43-48). Teacher can ask students to listen to a talk describing some people's personalities. Students list down each person personality and decide what type of job is the most suitable for them. An extended activity can be given to the students in which they are asked to list down their own personalities and decide a job that is good for them. A 'Bad Cold' dictation exercise is a fill-in gap exercise that requires the teacher to sneeze or cough at certain point to leave out some of the words in a listening text (p.54). Students listen to the teacher and try to find out the appropriate words when the teacher sneezes or coughs. Similarly, Gaps and 
Dictations exercise also requires students to fill in gaps (Alsadat and Hassankiadeh, 2013, p.132). Teacher does not sneeze or cough, but puts students in two groups facing each other. Teacher then asks each of them to shout a dictation text to his/her partner who will write the text.

Concerning note-taking and writing skills, teacher can give students such dictation activities as Dicto-comp/dictogloss, keywords dictation, music dictation, running dictation (p.56). Dicto-comp/dictogloss requires students to understand the main ideas of a listening text they hear and to take note the keywords of the text. Using the keywords, students then discuss the ideas in groups and rewrite the text (p.62). Keyword dictation encourages students to work more creatively. Students hear only keywords or phrases of a listening text and using the keywords they are asked to write a new text (p.72). Teacher can provide the outline of the text to help students organize the text. In music dictation, students complete the missing words or phrases of a song (p.57). The repeated sentence structures in the song might help students find keywords and learn the language structures of the sentences used. Running dictation is good for kinesthetic type of learners. Students work in pairs; a runner reads a phrase or sentence placed on the wall and a writer writes the phrase or sentence read by the runner (p.58). Pictures or texts can also be used for this kind of dictation.

Dictation exercise that combines translation and dictation is called trans-dictation which was introduced by Farhady and Khany (1997 in Alsadat and Hassankiadeh (2013, p.131). In this kind of dictation, students first listen to a text dictated by their teacher. The second time of listening the text, the students translate the text in their native language. Finally, students read their translation and write the dictation. Farhady and Khany claim that such dictation activity is "a highly valid and reliable measure of language proficiency” (Alsadat and Hassankiadeh, 2013, p.131).

\section{METHODS}

\section{A. Participants}

The participants of this study were 37 EFL students taking the Listening for Monologues class at STBA-LIA Yogyakarta. The Listening to Monologues class aims at training the students how to listen to talks/lectures and take notes effectively, and to develop students' listening strategies in understanding 
and taking notes of various talks/lectures. Dicto-comp is usually used by the teacher in the class as it can develop students' listening and note-taking skills.

This study took the running classes (A, B, and C) at STBA LIA Yogyakarta in the even semester in 2015. Group A and B were the experimental groups, and Group C was the control group. Since several students in those three groups did not take either the pre- or post-test administered to get the data of this research, only 17 out of 24 students in Group A was used to get the data. As for Group B, 9 out of 16 students were used to get the data and for Group C, 11 out of 13 students.

Group A received full dictation exercises and Group B received partial dictation exercises during the treatment period in addition to the dicto-comp listening exercises provided in their class textbook Lecture Ready 1 by Sarosy and Sherak (2007). Group C only received dicto-comp listening exercises in the textbook Lecture Ready 1. When using dicto-comp, the students noted down key words and ideas while listening to a listening text/a lecture, and then reconstructed the text/lecture using the key words and ideas. The teacher would then ask the students to proofread their own notes before discussing the lecture with their friends. In Group C, the teacher would remind the students to notice their spelling and grammar in their notes or would point out their grammatical mistakes.

\section{B. Instruments}

Each group had 11 sessions in class. A pre-test which measured the students' basic listening competence in understanding short lectures in English and which found out the homogeneity among the three groups was given in the first session of the class. A post-test which was the same as the pretest was administered to the three groups in the last session of the class to assess the students' achievement.

The test was designed based on the objective of the Listening to Monologues class which was to develop students' listening strategies in understanding and taking notes of various talks/lectures effectively. In the test, the students listened to two short lectures. The first lecture (Part 1 of the test) had 9 items in which the students were asked to get six main points about the lecture and to answer three questions based on the lecture. The second lecture (Part 2) had 3 items which required the students to take notes and rewrite three main points of the lecture in three sentences. To score the test the following rules were applied: 
1. Every correct idea/answer with no grammatical or spelling errors in Part 1 of the test was scored one point, while that of Part 2 was given two points. Thus, the total point of Part 1 and 2 was 15 (9 points for Part 1 and 6 points for Part 2).

2. Spelling errors and comprehension errors which include phonological and grammatical mistakes in each item of Part 1 would make the students lose half $(0.5)$ point even though they wrote a correct idea or answer, while that of Part 2 would make students lose one point. Thus, when students wrote correct ideas/answers to all items of the test but with spelling and grammatical mistakes in all those items they would lose 7.5 points. Alkire (2002) notes that teacher needs to notice comprehension errors and spelling errors to assess students' transcriptions. Comprehension errors refer to phonological mistakes such as the spelling of the word poor as pure, sign as saint, and grammatical mistakes such as writing She has two sisters as She have two sister, She'll start working next week as She's start working next week. Spelling errors would be like writing exercise as excersise, schedule as scedule, and volunteer as voulenteer.

3. Incorrect ideas or answers and difficult words to read were given no points.

At the end of the treatment period, all students (40 students) in Group A and B, including those who did not take the pre- or posttest but received the treatments, were given a questionnaire. The questionnaire used a 5-point Likert-scale to find out the students' comments for the dictation exercises they received in their class. It measured the effectiveness of the dictation exercises in developing the students' awareness of spelling words, in helping the students use correct vocabulary in context, and in developing their awareness of using grammar.

\section{Procedure}

The treatments were given over 9 meetings to the experimental groups. In each meeting before students did listening exercises in their class module which required them to apply dicto-comp, the students in group A were given a full dictation exercise, while group $B$ received a partial dictation exercise. The dictation was sentence level dictation. Each consisted of five sentences 
delivered by a native speaker of English which were played on an $\mathrm{mp} 3$ player in a computer by the teacher who was also the researcher. A room speaker was used for the students to listen to the sentences. Each sentence was played three times so that the students could re-check their writing. The sentences chosen for the dictation exercises were those that elicited the students to be aware of typical grammatical errors they made in writing English sentences such as omissions of the - s ending in plural nouns, the $-\mathrm{s}$ ending in the third person singular verbs, and the -ed ending in the regular past participles.

As Group A received full dictations, they did not get any clues given by the teacher. Group B, on the other hand, was given one word as a clue of each sentence. The word was the first word or the subject of each sentence. It was aimed to help the students aware of the number of the subject of a sentence which then might help them notice the form of the verb following it.

The dictation exercise was then discussed together with the teacher. Students swapped their dictation sheet with other student to check against the original sentences displayed by the teacher on the whiteboard. Students circled any errors produced on the sheet. The dictation sheets were then collected by the teacher to be examined and were returned to the students in the next meeting. Students were expected to notice any errors they made when they received their dictation sheets before they had another dictation exercise in the next meeting.

\section{Data analysis}

A paired-samples test was conducted to compare the means of each group's pre and post-test in order to investigate the significant difference of those two tests in each group. HO is rejected when the p-value is lower than 0.05 which indicates that there was a significant difference between the preand post-tests of each group. The mean gain scores of the three groups were then compared to find out which group improved better on the post-test.

To get the answer of Research Question 2, a descriptive analysis of the grammar points in the post-tests of the three groups was carried out. The results of the experimental groups were further examined to see the improvement of each group's awareness of using their knowledge of grammar in reproducing a listening text. Frequency in percentage was used to indicate the improvement of the students' awareness in applying their grammar knowledge in reproducing a listening text. 
To analyze the Likert-scale responses in the questionnaire, the frequency distribution of each experimental group's answers was presented. It was then interpreted to examine the comments of students in Group A and B for the dictation exercises they received.

\section{FINDINGS}

\section{A. Paired-Samples Tests}

The paired-samples test is to compare the means of each group's pre and post-test in order to see the significant difference of those two tests in each group. Table 1 shows the paired-samples descriptive statistics and Table 2 displays the paired-samples test of Group A, B, and C.

Table 1

Paired-Samples Statistics

\begin{tabular}{lllllrr}
\hline & & Mean & N & $\begin{array}{c}\text { Std. } \\
\text { Deviation }\end{array}$ & $\begin{array}{c}\text { Std. } \\
\text { Error } \\
\text { Mean }\end{array}$ \\
\hline \multirow{2}{*}{ Group A } & \multirow{2}{*}{ Pair 1 } & pretest & 6.76 & 17 & 3.118 & .756 \\
\cline { 3 - 7 } & posttest & 8.06 & 17 & 2.200 & .534 \\
\hline \multirow{2}{*}{ Group B } & \multirow{2}{*}{ Pair 1 } & pretest & 5.39 & 9 & 3.229 & 1.076 \\
\cline { 3 - 7 } & posttest & 7.56 & 9 & 2.877 & .959 \\
\hline \multirow{2}{*}{ Group C } & \multirow{2}{*}{ Pair 1 } & pretest & 8.32 & 11 & 2.601 & .784 \\
\cline { 3 - 7 } & posttest & 10.36 & 11 & 3.163 & .954 \\
\hline
\end{tabular}

The mean score of pre-test of Group A was 6.76 and that of the post-test was 8.06. The gain score was 1.3 suggesting that Group A improved their performance on the post-test. The standard deviation of the post-test decreased from 3.118 to 2.200 indicating that the students' post-test scores were closer to the expected value. Group B's mean of the post-test (7.56) was higher than that of the pre-test (5.39). The gain score was 2.17 which was higher compared to that of Group A. Just as Group A, the standard deviation of the post-test (2.877) was also lower than that of the pre-test (3.229). As for Group C, the mean of post-test and pre-test was 10.36 and 8.32 respectively. The gain score of the post-test was 2.04. Group C also shows better performance on the post-test. The post-test standard deviation (3.163), however, was higher than the pre-test (2.601) showing that the post-test scores 
were further from the mean compared to the pre-test scores. Table 2 illustrates the results of the groups' paired-sampled test.

Table 2

\section{Paired-Samples Test}

\begin{tabular}{|c|c|c|c|c|c|c|c|c|c|c|}
\hline & & & \multicolumn{5}{|c|}{ Paired Differences } & \multirow{3}{*}{$\mathrm{T}$} & \multirow{3}{*}{$\mathrm{df}$} & \multirow{3}{*}{$\begin{array}{l}\text { Sig. } \\
(2- \\
\text { tailed })\end{array}$} \\
\hline & & & \multirow[t]{2}{*}{ Mean } & \multirow[t]{2}{*}{$\begin{array}{c}\text { Std. } \\
\text { Deviation }\end{array}$} & \multirow[t]{2}{*}{$\begin{array}{l}\text { Std. } \\
\text { Error } \\
\text { Mean }\end{array}$} & \multicolumn{2}{|c|}{$\begin{array}{c}95 \% \\
\text { Confidence } \\
\text { Interval of the } \\
\text { Difference }\end{array}$} & & & \\
\hline & & & & & & Lower & Upper & & & \\
\hline $\begin{array}{l}\text { Group } \\
\text { A }\end{array}$ & $\begin{array}{l}\text { Pair } \\
1 \\
\end{array}$ & $\begin{array}{l}\text { pretest- } \\
\text { posttest } \\
\end{array}$ & $1.294^{-}$ & 2.158 & .523 & -2.404 & -.184 & $2.472^{-}$ & 16 & .025 \\
\hline $\begin{array}{l}\text { Group } \\
\mathrm{B}\end{array}$ & $\begin{array}{l}\text { Pair } \\
1 \\
\end{array}$ & $\begin{array}{l}\text { pretest- } \\
\text { posttest }\end{array}$ & 2.167 & 1.854 & .618 & -3.592 & -.742 & 3.506 & 8 & .008 \\
\hline $\begin{array}{l}\text { Group } \\
\text { C }\end{array}$ & $\begin{array}{l}\text { Pair } \\
1 \\
\end{array}$ & $\begin{array}{l}\text { pretest- } \\
\text { posttest }\end{array}$ & $\begin{array}{r}- \\
2.045\end{array}$ & 2.252 & .679 & -3.559 & -.532 & 3.012 & 10 & .013 \\
\hline
\end{tabular}

The paired-samples test on the pre- and post-test of Group A shows that the p-value was 0.025 which was less than 0.05. It confirmed that Group A statistically improved on the post test. The p-value of Group B was 0.008 which was lower than 0.05 . It indicates that there was a significant difference between the pre-test and the post-test scores of the students who were given partial dictations. In addition, the calculation for Group $\mathrm{C}$ indicates the $\mathrm{p}$ value of 0.013 which was smaller than 0.05 . In other words, Group C also shows a significant difference in their scores on pre- and post-tests.

\section{B. Analysis of Grammar Points}

A descriptive analysis of the grammar points in the post-tests of the experimental groups was carried out to examine the improvement of each group's awareness of using their knowledge of grammar in reproducing a listening text.

The difference in scores between the pre- and post-test of each student in Group A is described in Table 3. The table includes the grammar points the students got in their pre- and post-tests. 
Table 3

Pre- and Post-test Scores

\begin{tabular}{|c|c|c|c|c|c|c|c|c|c|c|c|c|}
\hline \multirow[b]{2}{*}{ Ss } & \multicolumn{4}{|c|}{ GROUP A } & \multicolumn{4}{|c|}{ GROUP B } & \multicolumn{4}{|c|}{ GROUP C } \\
\hline & $\begin{array}{l}\text { Pre- } \\
\text { test }\end{array}$ & $\begin{array}{c}\text { Gr. } \\
\text { points }\end{array}$ & $\begin{array}{c}\text { Post- } \\
\text { test }\end{array}$ & $\begin{array}{c}\text { Gr. } \\
\text { points }\end{array}$ & $\begin{array}{l}\text { Pre- } \\
\text { test }\end{array}$ & $\begin{array}{c}\text { Gr. } \\
\text { points }\end{array}$ & $\begin{array}{c}\text { Post- } \\
\text { test }\end{array}$ & $\begin{array}{c}\text { Gr. } \\
\text { Points }\end{array}$ & $\begin{array}{l}\text { Pre- } \\
\text { test }\end{array}$ & $\begin{array}{c}\text { Gr. } \\
\text { points }\end{array}$ & $\begin{array}{c}\text { Post- } \\
\text { test }\end{array}$ & $\begin{array}{c}\text { Gr. } \\
\text { points }\end{array}$ \\
\hline 1 & 9 & 2.5 & 10.5 & 3.5 & 1 & 0.5 & 6 & 0.5 & 12.5 & 6 & 14.5 & 7 \\
\hline 2 & 13 & 5.5 & 11.5 & 4 & 7 & 3 & 11 & 4 & 4 & 0 & 8 & 2.5 \\
\hline 3 & 6 & 1.5 & 8 & 2 & 9.5 & 3.5 & 8.5 & 3.5 & 8.5 & 3.5 & 6 & 1 \\
\hline 4 & 3 & 0 & 4 & 0.5 & 1 & 0 & 3.5 & 1 & 6 & 1.5 & 8.5 & 2.5 \\
\hline 5 & 2.5 & 0 & 7 & 1.5 & 4 & 0 & 5 & 0.5 & 9 & 3 & 11 & 5 \\
\hline 6 & 3 & 0.5 & 4.5 & 0 & 4.5 & 0 & 5 & 0.5 & 7.5 & 3 & 13.5 & 6 \\
\hline 7 & 8.5 & 3 & 10 & 4.5 & 6.5 & 1 & 8.5 & 3 & 8.5 & 2.5 & 11.5 & 4.5 \\
\hline 8 & 10 & 3 & 11 & 3.5 & 5 & 0.5 & 8.5 & 3 & 6.5 & 1.5 & 9 & 3.5 \\
\hline 9 & 3 & 1 & 6 & 1 & 10 & 3.5 & 12 & 4.5 & 12 & 4.5 & 14 & 6.5 \\
\hline 10 & 9.5 & 3 & 8 & 2.5 & & & & & 6.5 & 1 & 5.5 & 1.5 \\
\hline 11 & 7 & 1 & 10 & 3 & & & & & 10.5 & 2.5 & 12.5 & 4.5 \\
\hline 12 & 7.5 & 2 & 7.5 & 2 & & & & & & & & \\
\hline 13 & 8 & 3 & 9 & 5 & & & & & & & & \\
\hline 14 & 8 & 1 & 8.5 & 2.5 & & & & & & & & \\
\hline 15 & 4 & 1 & 9 & 4 & & & & & & & & \\
\hline 16 & 3.5 & 0.5 & 6.5 & 1.5 & & & & & & & & \\
\hline 17 & 9.5 & 3 & 6 & 1.5 & & 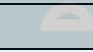 & & & & & & \\
\hline
\end{tabular}

Note: Ss = student, Gr. = grammar

Most of the students (82\%) in Group A performed better on the posttest. Their gain score of the post-test were between 0.5 and 5 . Their grammar points increased between 0.5 and 3 points. Only one student (student 15) shows a great change on the post-test. His score raised 5 points in which his grammar points increased by 3 points. However, three students (student 2, 10 and 17) in the group decreased by $1.5,1.5$, and 3.5 points respectively on the post-test scores. It can be seen that the three students' grammar points also decreased. Student 9 had better score in his post-test, but his grammar points remained the same indicating that his post-score increased due to the points he got for his correct ideas/answers not because of an increase in the grammar points.

Just like Group A, 89\% of the students in Group B got better scores on the post-test. The gain score from the pre-test to post-test was also between 0.5 and 5. Regarding the grammar points, they increased between 0.5 and 2.5 points. Student 1 had a great change as her score increased by 5 points. Yet, her grammar points stayed the same. One student (student 3 ) decreased by 1 
point on his post-test score, but his grammar points stayed the same. Three students (student 4, 5, and 6) who did not get any grammar point in their pretest gained points in the post-test even though they only got 0.5 to 1 point. Thus, none of the students in this group decreased their points of grammar.

In Group C, out of 11 students, 90\% raised their post-test scores between 2 and 6 points. Concerning grammar points, it can be seen that they increased by 0.5 to 3 points. Student 6 improved a lot in his post test. His grammar increased by 3 points. On the other hand, two students (student 3 and student 10) decreased their scores by 2.5 and 1 points respectively. Only student 3 who decreased his grammar points from 3.5 to 1 .

\section{Questionnaire}

The results of questionnaire given after the treatments to all respondents in Group A and B were described in Table 4. The three statements in the questionnaire which were to assess students' responses towards the dictation exercises given in their class applied a 5-point scale where 1 indicates not effective at all, 2 not too effective, 3 okay (somewhat ineffective or somewhat effective), 4 effective, and 5 very effective. The frequency of Group A and B's answers was put in percentage.

Table 4

Group A \& B's Percentage of Questionnaire

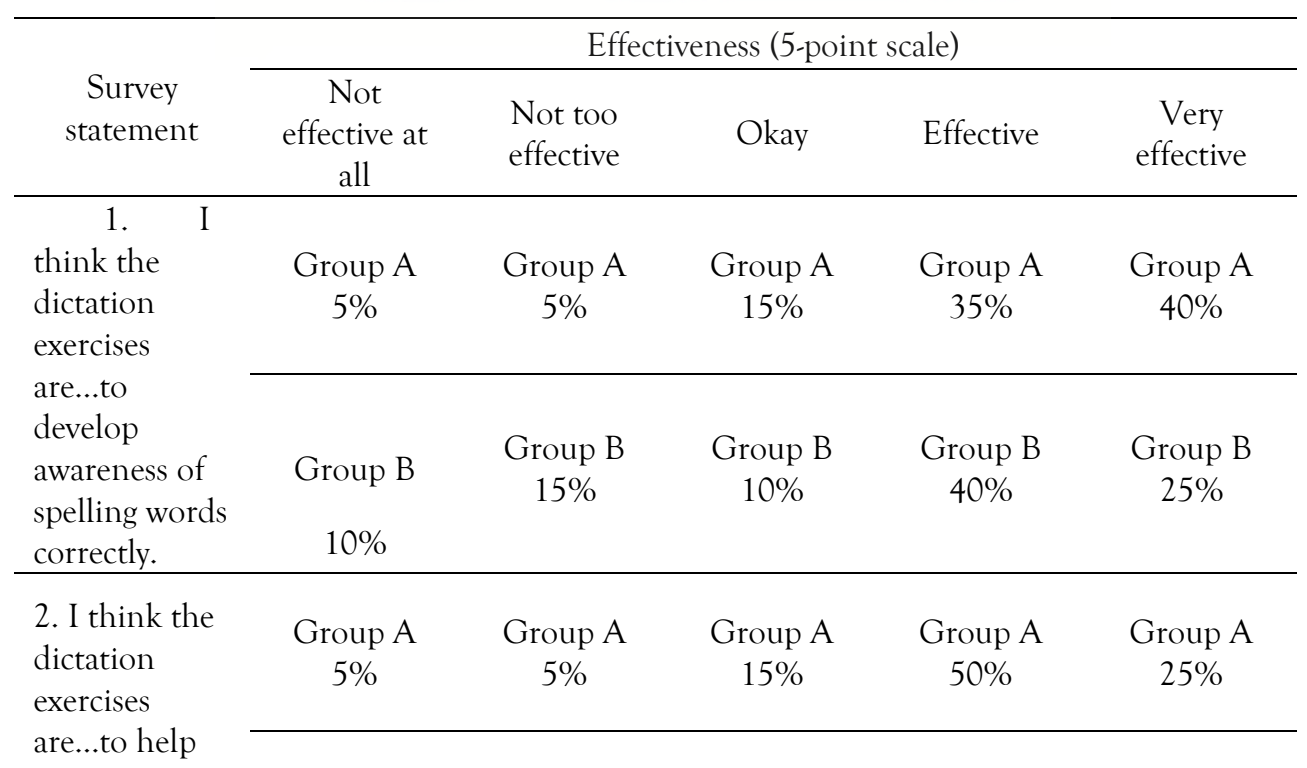


234 Celt, Volume 16, Number 2, December 2016, pp. 217-241

\begin{tabular}{|c|c|c|c|c|c|}
\hline $\begin{array}{l}\text { me use the } \\
\text { correct } \\
\text { vocabulary in } \\
\text { context. }\end{array}$ & $\begin{array}{c}\text { Group B } \\
5 \%\end{array}$ & $\begin{array}{c}\text { Group B } \\
5 \%\end{array}$ & $\begin{array}{c}\text { Group B } \\
25 \%\end{array}$ & $\begin{array}{c}\text { Group B } \\
45 \%\end{array}$ & $\begin{array}{c}\text { Group B } \\
20 \%\end{array}$ \\
\hline $\begin{array}{l}\text { 3. I think the } \\
\text { dictation } \\
\text { exercises } \\
\text { are...to } \\
\text { develop } \\
\text { awareness of } \\
\text { using }\end{array}$ & $\begin{array}{c}\text { Group A } \\
0 \%\end{array}$ & $\begin{array}{c}\text { Group A } \\
10 \%\end{array}$ & $\begin{array}{c}\text { Group A } \\
10 \%\end{array}$ & $\begin{array}{c}\text { Group A } \\
60 \%\end{array}$ & $\begin{array}{c}\text { Group A } \\
20 \%\end{array}$ \\
\hline $\begin{array}{l}\text { grammar } \\
\text { knowledge to } \\
\text { proofread } \\
\text { what I wrote. }\end{array}$ & $\begin{array}{c}\text { Group B } \\
\text { ०\% }\end{array}$ & $\begin{array}{c}\text { Group B } \\
5 \%\end{array}$ & $\begin{array}{c}\text { Group B } \\
15 \%\end{array}$ & $\begin{array}{c}\text { Group B } \\
50 \%\end{array}$ & $\begin{array}{c}\text { Group B } \\
30 \%\end{array}$ \\
\hline
\end{tabular}

The questionnaire results demonstrate that as many as $35 \%$ of the students in Group A thought that dictation exercises are effective to develop their awareness of spelling words correctly and $40 \%$ of them considered it very effective. Only 5\% viewed the dictation exercises as not effective at all and not too effective to develop their spelling skill. As for the second statement of the questionnaire which assessed how effective are the dictation exercises to help the students use correct vocabulary in context, $50 \%$ of the students considered it effective and $25 \%$ very effective. The response to the third statement of the questionnaire concerning the effectiveness of dictation exercises to develop students' awareness of using grammar knowledge to proofread their writing indicated that a majority of the students (60\%) thought the dictation exercises effective and $20 \%$ very effective. None of the students considered it 'not effective at all'.

The answers of students in Group B did not show much difference from those of Group A. Regarding the effectiveness of dictation to develop spelling skill, $40 \%$ of the students considered it effective and $25 \%$ of them very effective. Students' responses to the second statement of the questionnaire indicated that $45 \%$ of the students perceived dictation exercises as effective in making them use proper vocabulary in context and $20 \%$ very effective. About half of the students $(50 \%)$ believed that dictation was effective to make them aware of applying knowledge of grammar in their work, and 30\% thought that it was very effective. 


\section{DISCUSSION}

As indicated in the results of the paired-samples tests, every group in this research performed better in the post-test. In other words, the students in the experimental groups and control group showed statistically significant improvement in reconstructing ideas of English lectures they heard. When the post-test answer sheets were examined, it was found that students tended to write more compared to when they had the pre-test. It seems that in the pretest they still had difficulty to get the main points of the short lectures given in the test so that some of the students left their answer sheets blank without any answer written. It was found that student 2 and student 17 in Group A decreased by 1.5 and 3.5 points respectively on their post-test scores (Table 3). The decrease in student 2 score was caused by his incomplete answers in Part 3 of the test which required the students to rewrite a lecture in three sentences, while that in student 1 was due to her incorrect answers in Part 2 of the test which asked students to give answers to three questions based on a lecture. Student 3 in Group B (Table 5.10) also decreased 1 point on his posttest score that is in his total scores in Part 3 of the test because of his sentences that were not relevant to the lecture. As for the control group (Group C), there were student 3 and student 10 who decreased their post-test scores by 2.5 and 1 points respectively (Table 3 ). Student 3 had more grammatical mistakes that is in the use of the $-\mathrm{s}$ in plural noun and more incomplete answers in Part 3, while student 10 had all wrong answers in Part 3 of the test even though gained more scores in Part 2. Those two students, however, still made mistakes in the use of the $-\mathrm{s}$ in third person singular in Part 1 of both the pre- and post-tests. In addition, student 6 who left some items blank in the pre-test could get more points for grammar and ideas in the post-test.

This indicated that the dicto-comp exercises given to all groups as the main listening exercises in the classes helped them to enforce their listening comprehension and note-taking skills in which they tried to get the main ideas and key words of the listening text and to reproduce the text in written form. It is in line with Nation's view (1991) that dicto-comp makes "learners have to remember the ideas in a text...and express them in the words of the original or in their own words (13-14)."

Furthermore, when the paired-samples descriptive statistics which show the means of the pre- and post-tests of those three groups are compared, Group B who had additional exercises with partial dictation had the highest mean gain score (2.17). Group A's mean gain score was 1.3, while Group C's was 2.04. It suggests that Group B showed better improvement in the post-test 
than Group A that was given full dictation exercises and Group C that only had dicto-comp exercises.

To confirm that the dictations exercises given to Group A and B improved the students' awareness of using their knowledge of grammar in their written language, Group A and B's grammar points on the post-tests and their answer sheets were examined further to see the difference in the grammar points between the two groups. It was found that $65 \%$ of the students in Group A improved their grammar points on the post-test, 12\% had the same grammar points as on the pre-test, and 23\% decreased their points of grammar (Table 3). Those who decreased their grammar points still produced grammatical mistakes in their writing such as in the use of the morpheme $-\mathrm{s}$ in third person singular and the $-\mathrm{s}$ plural (e.g. She has two step sisters). In Group B, as many as 78\% of the students increased their grammar points on the post-test, $22 \%$ had the same points as on the pre-test, and none of them showed a decrease in their grammar points (Table 3). Even though both groups showed improvement in grammar points, it can be observed that Group B had better performance in grammar than Group A. The teacher in Group A and B did not remind the students to check their grammar when they proofread their written version of the text they heard. The dictation exercises made them aware of using their grammar knowledge to self-correct and self-edit their own work. On the other hand, Group C still received reminder and pointers from their teacher to proofread what they wrote, i.e. to always check especially the morpheme $-s$ in third person singular, the $-s$ in plural nouns and the spelling of the words they wrote. This made as many as 91\% of the students in Group C increased their grammar points on the posttest (Table 3).

This finding supports Morris (1983) who claims that dictation exercises can foster students' accuracy in listening and writing as they provide students with listening comprehension skills and train them to recognize not only incorrect spelling but also inconsistencies in grammar. Similarly, Hoare and Tanner (2008) note that dictation exercises at sentence level or longer motivate noticing, accuracy, rereading as well as "enforce listening-writing transfer skills" (p.763). Nation (1991) also believes that sentence level dictation gives students focus on the accuracy of constructing phrases and clauses. Furthermore, students in Group B demonstrated less grammatical errors in their post-test, especially in producing sentences with the -s plural noun and with simple present tense. This suggests that they became better aware of applying their grammar knowledge in rewriting the listening text they heard. This confirms Alkire (2002) who points out that dictation increases 
students' awareness of spelling errors as well as comprehension errors which includes phonological and grammatical errors. Also, it supports Kondo's study (2005) who found that dictation as a listening exercise indeed encouraged students to utilize their knowledge of grammar.

The questionnaire results also support the statistical findings and the grammar points descriptive analysis of this study as a majority of the students in the experimental groups perceived the dictation exercises as effective to make them aware of spelling words properly, of utilizing vocabulary based on context, and of applying their grammar knowledge to proofread their work. None of the students in both groups considered the dictation exercises ineffective at all to raise their awareness of grammar in rewriting a text.

Using dictation as listening exercises has been recommended by some ELT experts (Nation, 1991; Morris, 1983; Alkire, 2002). Dictation is useful not only to develop listening skills, but also to help develop writing skill. Considering the positive effects seen in Group A and B, dictation is considered a beneficial exercise in a language classroom. It provides practice in many language aspects and can aid the development of the four language skills when used in an integrative way.

\section{CONCLUSION}

The dictation exercises provided to the experimental groups in this research in addition to the dicto-comp implemented in the classes proved to encourage the students to apply their grammar knowledge to check their writing during and after dictation. Analysis of the data of the pre- and posttests through paired-samples tests found that both experimental groups performed better in the post-test, and so did the control group. Yet, the group who had exercises with partial dictation showed higher gain score. Moreover, the group who received partial dictation exercises made better improvement in their grammar accuracy than the group who had full dictation exercises. The control group also improved their grammar points but they received their teacher's help to point out their grammatical mistakes and spelling errors. The results thus indicate those two types of dictations contributed to the students' consciousness-raising of grammar knowledge. The dictation exercises facilitated the development of self-correcting habit which was not seen in the control group who still needed some language input from the teacher to proofread their work. The result of questionnaire concerning the effectiveness 
of the dictation exercises reported in this research also reveals that the students in the experimental groups viewed the dictation exercises they had as effectively enhancing their spelling, the use of proper words in context, and the use of grammar knowledge to proofread students' works. Dictation is recommended to be used in EFL classes. It can be implemented not only to develop listening comprehension skills, but also to develop autonomy in learning as it provides learners with opportunities to perform their ability in various language skills and language aspects.

\section{REFERENCES}

Alkire, S. (2002). Dictation as a language learning device. The Internet TESL Journal, VIII (3). Retrieved October 6, 2015 from http://itestj.org/ Techniques/Alkire-Dictation.html

Alsadat, M. \& Hassankiadeh, G.. (2013). Active and passive dictation. International Journal of Evaluation and Research in Education, 2 (3), 129. 134. Retrieved October 7, 2015 from http://download.portalgaruda.org/article. php?article=6078\&val=159

Frodesen, J. (2001). Grammar in writing. Teaching English as a Second or Foreign Language. $3^{\text {rd }}$ Edition. Marianne Celce-Murcia. pp. 233-248. Boston: Heinle \& Heinle, Thomson Learning, Inc.

Habibi, P., Azadeh, N., \& Habibi, S. (2012). The role of listening comprehension in dictation. Indian Journal of Science and Technology, 5 (8), 3208-3210. Retrieved April 10, 2015 from www.indjst.org/index.php/indjst/article/download/30542/26467

Hoare, P. \& Tanner, P. (2008). The benefits of dictation for university writing students and teachers. PAC7 at JALT2008 Conference Proceedings. pp. 758-764. Retrieved October 7, 2015 from http://jalt-publications.org/ recentpdf/proceedings/2008/E160.pdf

Kiany, G. R. \& Shiramiry, E. (2002). The effect of frequent dictation on the listening comprehension ability of elementary EFL learners. TESL Canada Journal, 20 (1), 57-63. Retrieved October 7, 2015 from http://files.eric.ed.gov/fulltext/EJ659412.pdf

Kondo, Y. (2005). Factor of listening comprehension evaluated by dictation. Proceedings of the $8^{\text {th }}$ Conference of Pan-Pacific Association of Applied 
Linguistics. pp. 223-228. Retrieved April 10, 2015 from http://www. paaljapan.org/resources/proceedings/PAAL8/pdf/pdf021.pdf

Kuo, Y. (2010). Using partial dictation of an English teaching radio program to enhance EFL learners' listening comprehension." Asian EFL Journal, 47, 4-29. Retrieved April 10, 2015 from http://asian-efljournal.com/PTA/October-2010-Kuo.pdf

Marzban, A. \& Abdollahi, M. (2013). The effect of partial dictation on the listening comprehension ability of Iranian intermediate EFL learners. International Research Journal of applied and Basic Sciences. 5(2), 238-244. Retrieved April 10, 2015 from http://www.irjabs.com/files_site/paperlist/r1428_1309141 60025.pdf

Morris, Susan. (1983). Dictation- a technique in need of reappraisal. ELT Journal, 1(2), 121-126. Retrieved October 7, 2015 from http://203.72.145.166/ ELT/ files/37-2-2.pdf

Nation, Paul. (1991). Dictation, dicto-comp, and related Techniques. English Teaching Forum. 29 (4), 12-14. Retrieved October 7, 2015 from http://www.victoria. ac.nz/lals/about/staff/publications/paul-nation/ 1991-Dictation.pdf

Norris, Robert W. (1993). Using creative dictation to manage, motivate, and activate large groups of false beginners. Fukuoka Women's Junior College Studies, 45, 71-82. Retrieved October 7, 2015 from http://www2.gol.com/ users/norris/articles/dict.html

Richards, J.C. and Schmidt, R. (2002). Longman Dictionary of Language Teaching and Applied Linguistics. $3^{\text {rd }}$ Edition. London: Pearson Education.

Sarosy, Peg and Sherak, Kathy. (2007). Lecture Ready 1. Oxford: Oxford University Press.

Takeuchi, Osamu. (1997). Dictation: Is it really effective for language teaching? Audio-Visual Education, 20, 55-63. Retrieved April 10, 2015 from http://www2.ipcku.kansai-u.ac.jp/ takeuchi/papers/av20. html

Tang, Qu. (2012). The effectiveness of dictation method in college English vocabulary teaching. Theory and Practice in Language Studies. 2 (7), 1472 1476. Retrieved April 10, 2015 from http://ojs.academy 
publisher.com/index.php/

tpls/article/viewFile/tpls020714721476/5061

Underwood, Mary. (1989). Teaching Listening. London: Longman.

Using dictation to develop pupil's listening and writing skills (2011). A resource package. English Language Education Section, Curriculum Development Institute, the Education Bureau, the Hong Kong Special Administrative Region. Retrieved October 6, 2015 from https://cd.edb.gov.hk/eng/dict/

\section{APPENDIX 1}

\section{Pre-Test and Post-Test}

Your name:

St. No.:

Class:

IA. Listen to a short lecture and complete the notes below.

- Cinderella is about

- Harry Potter is about

Write 4 similarities of the two stories:

1.

2.

3.

4.

IB. Based on the lecture and your notes, answer the questions below.

1. How many relatives do Cinderella and Harry Potter have?

2. What wish that characters in both fairy tales have?

3. What is the miracle in both stories? 
II. Listen to a short lecture and write three (3) sentences about the information in the lecture.

1)

2)

3)

\section{APPENDIX 2}

\section{Questionnaire}

This questionnaire is to find out your responses towards the dictation exercises you did in class. Your answers will not affect your course grade. All responses will remain anonymous. Please respond to all questions. Thank you for your cooperation.

Respond to the questions below by circling the answer that represents your opinion.

1. I think the dictation exercises are..........to develop awareness of spelling words correctly.

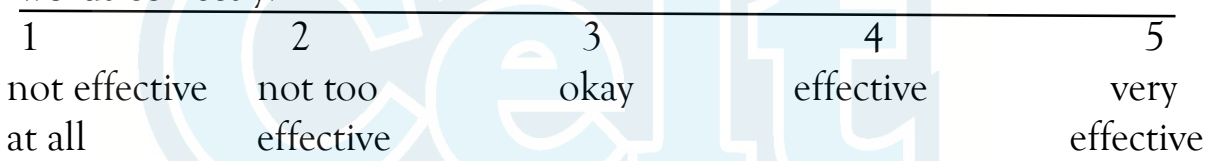

2. I think the dictation exercises are.

to help me use the correct vocabulary in context.

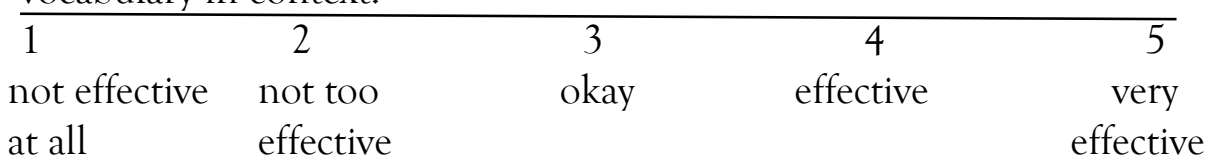

3. I think the dictation exercises are.

to develop awareness of using grammar knowledge to proofread what I wrote.

\begin{tabular}{llccr}
\hline 1 & 2 & 3 & 4 & 5 \\
not effective & not too & okay & effective & very \\
at all & effective & & & effective
\end{tabular}

Note:

okay $=$ somewhat ineffective, somewhat effective 